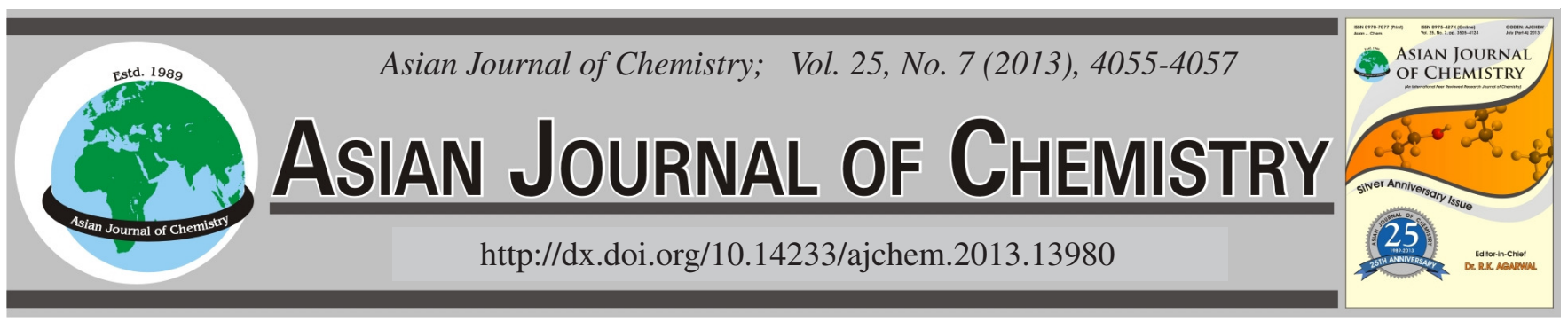

\title{
Synthesis and Supramolecular Structure of Bis-zinc(II) \\ Tetraformate Tetrahydrate Polymer $\left[\mathrm{Zn}_{2}\left(\mathrm{HCOO}^{-}\right)_{4}\left(\mathrm{H}_{2} \mathrm{O}\right)_{4}\right]_{\mathrm{n}}$
}

Li WAnG ${ }^{*}$, Xiu-Yan Dong, Li ZhaO and Yu-Hua Yang

School of Chemical and Biological Engineering, Lanzhou Jiaotong University, Lanzhou 730070, P.R. China

*Corresponding author: E-mail: wangli_78@126.com

(Received: 27 April 2012;

Accepted: 25 January 2013)

AJC-12753

\begin{abstract}
The polymeric compound bis-zinc(II) tetraformate tetrahydrate with the m.f. $\left[\mathrm{Zn}_{2}\left(\mathrm{HCOO}^{-}\right)_{4}\left(\mathrm{H}_{2} \mathrm{O}\right)_{4}\right]_{\mathrm{n}}$, was synthesized unexpectively by the reaction of zinc(II) acetate dihydrate with 2,2'-[1,1'-(propane-1,3-diyldioxy)bis(nitrilomethylidyne)]di-1-naphthol $\left(\mathrm{H}_{2} \mathrm{~L}\right)$ in ethanol. The molecule crystallizes in the monoclinic system, adopts a polymer conformation. The crystal structure indicates that it is an infinite three-dimension supramolecular network complex.

Key Words: Monooxime compound, Synthesis, Crystal structure, Supramolecular interaction.

ᄂ - - - - - - - - - - - - - - - - - - - - - - - - -
\end{abstract}

\section{INTRODUCTION}

Salen-type compound is a chelate ligand consisting of two nitrogen and two oxygen donors, capable of forming stable metal complexes ${ }^{1-3}$. Various functional Salen-metal complexes have been synthesized by complexation with the appropriate metal sources ${ }^{4-7}$. And salen-metal complexes can be used to obtain non-linear optical materials ${ }^{8}$, biological systems ${ }^{9}$, interesting magnetic properties ${ }^{10}$ and building blocks for cyclic supramolecular structures ${ }^{11}$. In this paper, complexation between a Salen-type bisoxime ligand $\mathrm{H}_{2} \mathrm{~L}$ (2,2'-[1, 1'-(propane1,3-diyldioxy)bis(nitrilomethylidyne)]di-1-naphthol) and zinc(II) acetate dihydrate has been studied. However, it is remarkable that the desired complex $[\mathrm{Zn}(\mathrm{L})]$ was not gained, but an unexpected bis-zinc(II) tetraformate tetrahydrate polymer $\left[\mathrm{Zn}_{2}\left(\mathrm{HCOO}^{-}\right)_{4}\left(\mathrm{H}_{2} \mathrm{O}\right)_{4}\right]_{\mathrm{n}}$, was obtained.

\section{EXPERIMENTAL}

2-Hydroxybenzaldehyde was purchased from Alfa Aesar and used without further purification. 1,3-Bis(aminooxy)propane was synthesized according to an analogous method reported earlier ${ }^{3}$. The other reagents and solvents were analytical grade reagents from Tianjin Chemical Reagent Factory. C, H and N analyses were carried out with a GmbH VariuoEL V3.00 automatic elemental analyzer. IR spectra in the range 4000$400 \mathrm{~cm}^{-1}$ were recorded on a VERTEX70 FT-IR spectrophotometer using $\mathrm{KBr}$ pellets. The ${ }^{1} \mathrm{H}$ NMR spectra were recorded on a Mercury-400BB spectrometer at room temperature using $\mathrm{CDCl}_{3}$ as solvent. X-Ray single crystal structure was determined on a Bruker Smart 1000 CCD area detector. Melting points were measured by the use of a microscopic melting point apparatus made in Beijing Taike Instrument Limited Company and the thermometer was uncorrected.

General procedure: 2,2'-[1,1'-(Propane-1,3-diyldioxy) bis(nitrilomethylidyne)]di-1-naphthol $\left(\mathrm{H}_{2} \mathrm{~L}\right)$ : A solution of 1,3bis(aminooxy)propane (106.2 mg, $1 \mathrm{mmol}$ ) in ethanol (5 mL) was added to a solution of 1-hydroxy-2-naphthaldehyde (344.8 $\mathrm{mg}, 2 \mathrm{mmol})$ in hot ethanol $(5 \mathrm{~mL})$ and the mixture was stirred at $328 \mathrm{~K}$ for $5 \mathrm{~h}$. After cooling to room temperature, colourless precipitates were collected on a suction filter, washed with ethanol and ethanol/hexane (1:4), respectively. The isolated compound was dried under reduced pressure and purified with recrystallization from ethanol to yield $259.4 \mathrm{mg}$ of crystalline solid. Yield 62.6 \%. m.p. 393-395 K. Anal. calcd. (\%) for: $\mathrm{C}_{25} \mathrm{H}_{22} \mathrm{~N}_{2} \mathrm{O}_{4}: \mathrm{C}, 72.45 ; \mathrm{H}, 5.35 ; \mathrm{N}, 6.76$. Found (\%): C, 72.23; $\mathrm{H}, 5.42 ; \mathrm{N}, 6.87$.

The unexpected present polymeric complex, biszinc(II) tetraformate tetrahydrate polymer, $\left[\mathrm{Zn}_{2}\left(\mathrm{HCOO}^{-}\right)_{4}\left(\mathrm{H}_{2} \mathrm{O}\right)_{4}\right]_{\mathrm{n}}$ was prepared from 2,2'-[1,1'-(propane-1,3-diyldioxy)bis(nitrilomethylidyne)]di-1-naphthol $\left(\mathrm{H}_{2} \mathrm{~L}\right)$ and zinc(II) acetate dihydrate. A solution of $\mathrm{Zn}$ (II) acetate dihydrate (5.2 mg, 0.024 $\mathrm{mmol})$ in ethanol $(6 \mathrm{~mL})$ was added dropwise to a solution of $\mathrm{H}_{2} \mathrm{~L}(9.9 \mathrm{mg}, 0.023 \mathrm{mmol})$ in THF $(5 \mathrm{~mL})$ at room temperature. The colour of the mixing solution turned to yellow immediately, the mixture was filtered and the filtrate was allowed to stand at room temperature for three weeks. Then the solvent partially evaporated and white prismatic single crystals suitable for X-ray analysis were obtained. Yield 35.7\%. Anal. calcd. (\%) 
for $\mathrm{C}_{4} \mathrm{H}_{12} \mathrm{O}_{12} \mathrm{Zn}_{2}\left(\left[\mathrm{Zn}_{2}\left(\mathrm{HCOO}^{-}\right)_{4}\left(\mathrm{H}_{2} \mathrm{O}\right)_{4}\right]_{\mathrm{n}}\right): \mathrm{C}, 12.55 ; \mathrm{H}, 3.16$; Zn, 34.15. Found (\%): C, 12.42; H, 3.07; Zn, 34.32.

X-Ray structure determination: The single crystal of the title polymeric complex, with approximate dimensions of $0.33 \mathrm{~mm} \times 0.30 \mathrm{~mm} \times 0.25 \mathrm{~mm}$ was placed on a Bruker Smart 1000 diffractmeter equipped with Apex CCD area detector. The diffraction data were collected using a graphite monochromated $\mathrm{MoK}_{\alpha}$ radition $(\lambda=0.71073 \AA)$ at $298(2) \mathrm{K}$. The structure was solved by using the program SHELXS-97 ${ }^{12}$ and Fourier difference techniques and refined by full-matrix leastsquares method on $\mathrm{F}^{2}$ using SHELXL-97 ${ }^{13}$. Details of the data collection and refinements of title compound are given in Table-1. The non-hydrogen atoms were refined anisotropically. Hydrogen atoms were added theoretically. CCDC: 684099.

\begin{tabular}{|c|c|}
\hline \multicolumn{2}{|c|}{$\begin{array}{c}\text { TABLE-1 } \\
\text { CRYSTAL DATA AND REFINEMENT } \\
\text { PARAMETERS FOR THE TITLE COMPLEX }\end{array}$} \\
\hline Empirical formula & $\mathrm{C}_{4} \mathrm{H}_{12} \mathrm{O}_{12} \mathrm{Zn}_{2}$ \\
\hline Formula weight & 382.88 \\
\hline Temperature & 298(2) K \\
\hline Wavelength & $0.71073 \AA$ \\
\hline Crystal system & Monoclinic \\
\hline Space group & $\mathrm{P} 2_{1} / \mathrm{c}$ \\
\hline Cell dimensions & $\begin{array}{l}\mathrm{a}=8.6501(10) \AA ̊ ., \mathrm{b}=7.1269(8) \AA \\
\mathrm{c}=9.2852(13) \AA, \beta=97.5800(10)\end{array}$ \\
\hline Volume & $567.42(12) \AA^{3}$ \\
\hline $\mathrm{Z}$ & 2 \\
\hline Density (calculated) & $2.241 \mathrm{mg} / \mathrm{m}^{3}$ \\
\hline Absorption coefficient & $4.287 \mathrm{~mm}^{-1}$ \\
\hline $\mathrm{F}_{(000)}$ & 384 \\
\hline Index ranges & $-7 \leq \mathrm{h} \leq 10,-8 \leq \mathrm{k} \leq 8,-11 \leq 1 \leq 10$ \\
\hline Reflections collected & 2577 \\
\hline Independent reflections & $983\left[\mathrm{R}_{\text {(int) }}=0.0935\right]$ \\
\hline Data/restraints/parameters & $983 / 0 / 85$ \\
\hline Goodness of fit indicator & 0.981 \\
\hline $\mathrm{R}[\mathrm{I}>2 \sigma(\mathrm{I})]$ & $\mathrm{R}_{1}=0.0444, \mathrm{wR}_{2}=0.1110$ \\
\hline Largest diff. peak and hole & 0.728 and -0.724 e. $\AA$ \\
\hline
\end{tabular}

\section{RESULTS AND DISCUSSION}

X-Ray crystallographic analysis revealed the crystal structure of title complex. And the structure is shown in Fig. 1. Selected bond distances and angles are listed in Table-2. The crystal structure of the title complex is built up by $\mathrm{Zn}_{2}\left(\mathrm{HCOO}^{-}\right)_{4}$ $\left(\mathrm{H}_{2} \mathrm{O}\right)_{4}\left(\mathrm{C}_{4} \mathrm{H}_{12} \mathrm{O}_{12} \mathrm{Zn}_{2}\right)$ structural units, in which all bond lengths are in normal ranges. The molecule crystallizes in the monoclinic system, adopts a polymer conformation. The zinc(II) (Zn1 and Zn2) ions linked by formate anions which coordinate to the two zinc(II) ions via a familiar Zn1-O-C-O-Zn2 coordinated mode. In the title complex, all the zinc(II) ions are six-coordinated forming a slightly distorted octahedral environment. The zinc(II) (Zn1) ion is six-coordinated by oxygen (O1, O3, O4, $\mathrm{O} 1 \mathrm{~A}, \mathrm{O} 3 \mathrm{~A}$ and $\mathrm{O} 4 \mathrm{~A}$ ) atoms from six formate anion groups. The O3, O3A, O4 and O4A atoms could be located in the equatorial plane and the two axial bonds form a straight line through the metal center $\left(\angle \mathrm{O} 1-\mathrm{Zn} 1-\mathrm{O} 1 \mathrm{~A}, 180^{\circ}\right)$. The axial Zn1-O1 bond length $(2.134(3) \AA)$ is longer by $0.076 \AA$ than the Zn1-O3 bond length (2.058(4) $\AA$ ) and by $0.042 \AA$ than the Zn1-O4 bond length (2.092(3) $\AA$ ). All the bond angles in the equatorial plane are very close to right angles $(\angle \mathrm{O} 1-\mathrm{Zn} 1-\mathrm{O} 3$, $\left.87.33^{\circ} ; \angle \mathrm{O} 1-\mathrm{Zn} 1-\mathrm{O} 4,87.23^{\circ}\right)$. Another zinc(II) ( $\left.\mathrm{Zn} 2\right)$ ion also coordinates to six oxygen (O5, O6, O2, O5A, O6A and O2A) atoms to form a slightly distorted octahedron, four oxygen (O5, O6, O5A and O6A) atoms coming from four coordinated water molecules and two oxygen ( $\mathrm{O} 2$ and $\mathrm{O} 2 \mathrm{~A})$ atoms belonging to two coordinated formates. The O5, O5A, O6 and O6A atoms could be located in the equatorial plane and the two axial bonds also form a straight line through the zinc(II) center $(\angle \mathrm{O} 2-$ $\mathrm{Zn} 2-\mathrm{O} 2 \mathrm{~A}, 180^{\circ}$ ). The axial Zn2-O2 bond length (2.153(4) $\AA$ ) is longer by $0.104 \AA$ than the Zn2-O5 bond length (2.049(4) $\AA$ ) and by $0.061 \AA$ than the Zn2-O6 bond length (2.092(4) $\AA$ ). The bond angles in the equatorial plane also approximate to right angles $\left(\angle \mathrm{O} 2-\mathrm{Zn} 2-\mathrm{O} 6,91.44^{\circ} ; \angle \mathrm{O} 2-\mathrm{Zn} 2-\mathrm{O} 5,89.84^{\circ}\right)$. The crystal structure indicates that it is an infinite three-dimension network complex.

TABLE-2

SELECTED BOND LENGTHS $(\AA ̊)$ AND ANGLES $\left({ }^{\circ}\right)$ FOR THE TITLE COMPLEX

\begin{tabular}{|c|c|c|c|c|c|}
\hline Bond & Lengths & Bond & Lengths & Bond & Lengths \\
\hline $\mathrm{Zn}(1)-\mathrm{O}(3)$ & $2.058(4)$ & $\mathrm{Zn}(1)-\mathrm{O}(1)$ & $2.134(3)$ & $\mathrm{Zn}(2)-\mathrm{O}(2)$ & $2.153(4)$ \\
\hline $\mathrm{Zn}(1)-\mathrm{O}(3)^{\# 1}$ & $2.058(4)$ & $\mathrm{Zn}(2)-\mathrm{O}(5)^{\# 4}$ & $2.049(3)$ & $\mathrm{Zn}(2)-\mathrm{O}(2)^{\# 4}$ & $2.153(4)$ \\
\hline $\mathrm{Zn}(1)-\mathrm{O}(4)^{\# 2}$ & 2.091(3) & $\mathrm{Zn}(2)-\mathrm{O}(5)$ & $2.049(3)$ & $\mathrm{O}(4)-\mathrm{Zn}(1)^{\# 5}$ & 2.091(3) \\
\hline $\mathrm{Zn}(1)-\mathrm{O}(4)^{\# 3}$ & $2.091(3)$ & $\mathrm{Zn}(2)-\mathrm{O}(6)$ & $2.092(4)$ & - & - \\
\hline $\mathrm{Zn}(1)-\mathrm{O}(1)^{\# 1}$ & $2.134(3)$ & $\mathrm{Zn}(2)-\mathrm{O}(6)^{\# 4}$ & $2.092(4)$ & - & - \\
\hline Bond & Angles & Bond & Angles & Bond & Angles \\
\hline $\mathrm{O}(3)-\mathrm{Zn}(1)-\mathrm{O}(3)^{\# 1}$ & 180.00 & $\mathrm{O}(4)^{\# 2}-\mathrm{Zn}(1)-\mathrm{O}(1)$ & $92.77(13)$ & $\mathrm{O}(6)^{\# 4}-\mathrm{Zn}(2)-\mathrm{O}(2)$ & $91.43(13)$ \\
\hline $\mathrm{O}(3)-\mathrm{Zn}(1)-\mathrm{O}(4)^{\# 2}$ & $90.48(13)$ & $\mathrm{O}(4)^{\# 3}-\mathrm{Zn}(1)-\mathrm{O}(1)$ & $87.23(13)$ & $\mathrm{O}(5)^{\# 4}-\mathrm{Zn}(2)-\mathrm{O}(2)^{\# 4}$ & $89.84(17)$ \\
\hline $\mathrm{O}(3)^{\# 1}-\mathrm{Zn}(1)-\mathrm{O}(4)^{\# 2}$ & $89.52(13)$ & $\mathrm{O}(1)^{\# 1}-\mathrm{Zn}(1)-\mathrm{O}(1)$ & 180.000 & $\mathrm{O}(5)-\mathrm{Zn}(2)-\mathrm{O}(2)^{\# 4}$ & $90.16(17)$ \\
\hline $\mathrm{O}(3)-\mathrm{Zn}(1)-\mathrm{O}(4)^{\# 3}$ & $89.52(13)$ & $\mathrm{O}(5)^{\# 4}-\mathrm{Zn}(2)-\mathrm{O}(5)$ & 180.000 & $\mathrm{O}(6)-\mathrm{Zn}(2)-\mathrm{O}(2)^{\# 4}$ & $91.43(13)$ \\
\hline $\mathrm{O}(3)^{\# 1}-\mathrm{Zn}(1)-\mathrm{O}(4)^{\# 3}$ & $90.48(13)$ & $\mathrm{O}(5)^{\# 4}-\mathrm{Zn}(2)-\mathrm{O}(6)$ & $90.76(14)$ & $\mathrm{O}(6)^{\# 4}-\mathrm{Zn}(2)-\mathrm{O}(2)^{\# 4}$ & $88.57(13)$ \\
\hline $\mathrm{O}(4)^{\# 2}-\mathrm{Zn}(1)-\mathrm{O}(4)^{\# 3}$ & 180.0 & $\mathrm{O}(5)-\mathrm{Zn}(2)-\mathrm{O}(6)$ & $89.24(14)$ & $\mathrm{O}(2)-\mathrm{Zn}(2)-\mathrm{O}(2)^{\# 4}$ & 180.000 \\
\hline $\mathrm{O}(3)-\mathrm{Zn}(1)-\mathrm{O}(1)^{\# 1}$ & $87.32(14)$ & $\mathrm{O}(5)^{\# 4}-\mathrm{Zn}(2)-\mathrm{O}(6)^{\# 4}$ & $89.24(14)$ & $\mathrm{C}(1)-\mathrm{O}(1)-\mathrm{Zn}(1)$ & $127.4(4)$ \\
\hline $\mathrm{O}(3)^{\# 1}-\mathrm{Zn}(1)-\mathrm{O}(1)^{\# 1}$ & $92.68(14)$ & $\mathrm{O}(5)-\mathrm{Zn}(2)-\mathrm{O}(6)^{\# 4}$ & $90.76(14)$ & $\mathrm{C}(1)-\mathrm{O}(2)-\mathrm{Zn}(2)$ & $133.0(4)$ \\
\hline $\mathrm{O}(4)^{\# 2}-\mathrm{Zn}(1)-\mathrm{O}(1)^{\# 1}$ & $87.23(13)$ & $\mathrm{O}(6)-\mathrm{Zn}(2)-\mathrm{O}(6)^{\# 4}$ & 180.0 & $\mathrm{C}(2)-\mathrm{O}(3)-\mathrm{Zn}(1)$ & $122.1(3)$ \\
\hline $\mathrm{O}(4)^{\# 3}-\mathrm{Zn}(1)-\mathrm{O}(1)^{\# 1}$ & $92.77(13)$ & $\mathrm{O}(5)^{\# 4}-\mathrm{Zn}(2)-\mathrm{O}(2)$ & $90.16(17)$ & $\mathrm{C}(2)-\mathrm{O}(4)-\mathrm{Zn}(1)^{\# 5}$ & $125.8(3)$ \\
\hline $\mathrm{O}(3)-\mathrm{Zn}(1)-\mathrm{O}(1)$ & $92.68(14)$ & $\mathrm{O}(5)-\mathrm{Zn}(2)-\mathrm{O}(2)$ & $89.84(17)$ & - & - \\
\hline $\mathrm{O}(3)^{\# 1}-\mathrm{Zn}(1)-\mathrm{O}(1)$ & $87.32(14)$ & $\mathrm{O}(6)-\mathrm{Zn}(2)-\mathrm{O}(2)$ & $88.57(13)$ & - & - \\
\hline
\end{tabular}

Symmetry transformations used to generate equivalent atoms: ${ }^{\# 1}-\mathrm{x}+2,-\mathrm{y}+1,-\mathrm{z}+1 ;{ }^{\# 2}-\mathrm{x}+2, \mathrm{y}+1 / 2,-\mathrm{z}+3 / 2 ;{ }^{\# 3} \mathrm{x},-\mathrm{y}+1 / 2, \mathrm{z}-1 / 2 ;{ }^{\# 4}-\mathrm{x}+1,-\mathrm{y}+2,-\mathrm{z}+1 ;{ }^{\# 5}-$ $\mathrm{x}+2, \mathrm{y}-1 / 2,-\mathrm{z}+3 / 2$. 


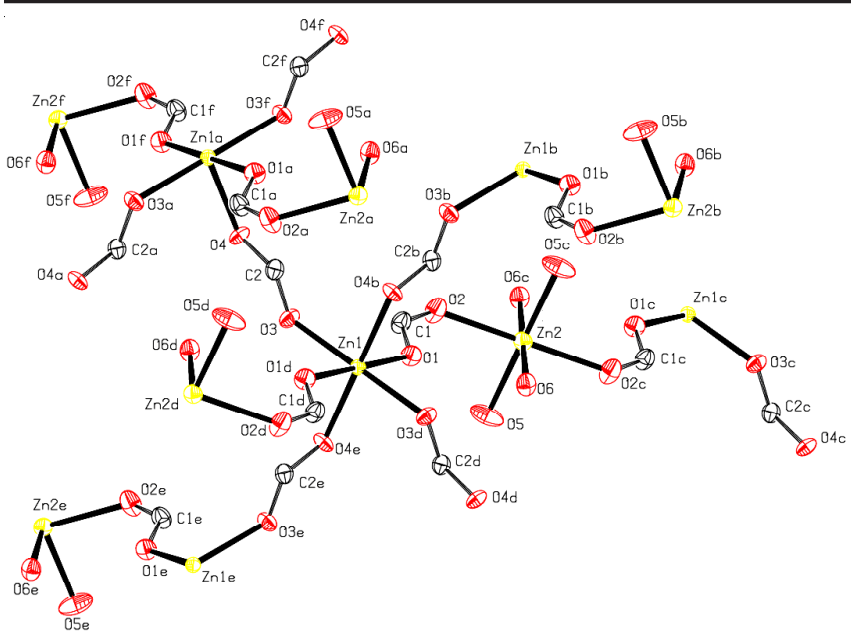

Fig. 1. Molecule structure of the title complex with atom numbering scheme. Displacement ellipsoids for non-hydrogen atoms are drawn at the $30 \%$ probability level

The introduction of coordinated water molecules successfully leads to the assembly of the complex by intermolecular hydrogen bonds. As illustrated in Fig. 2, the intramolecular O6-H6A …01 hydrogen bonds involving the hydroxyl groups and formic acid oxygen atoms generate $\mathrm{S}(6)$ ring motifs. Moreover, the intermolecular O6-H6B $\cdots \mathrm{O} 3$ and $\mathrm{O} 5-\mathrm{H} 5 \mathrm{~B} \cdots \mathrm{O} 4$ hydrogen bonds link neighbouring molecules into $\mathrm{R}_{2}^{2}(8)$ ring graph-motifs and form an infinite 2D-layer supramolecular structure on the ab crystallographic plane (Fig. 3). Simultaneously, this linkage is further stabilized by the intermolecular O5-H5A … 2 hydrogen bonds to form an infinite three-dimensional supramolecular network structure (Table-3, Fig. 4).

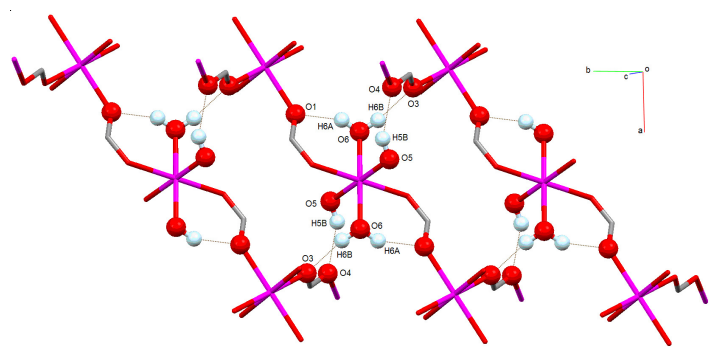

Fig. 2. View of $S(6)$ and $R_{2}{ }^{2}(8)$ ring motifs generated by intramolecular and intermolecular hydrogen bonds of the title complex

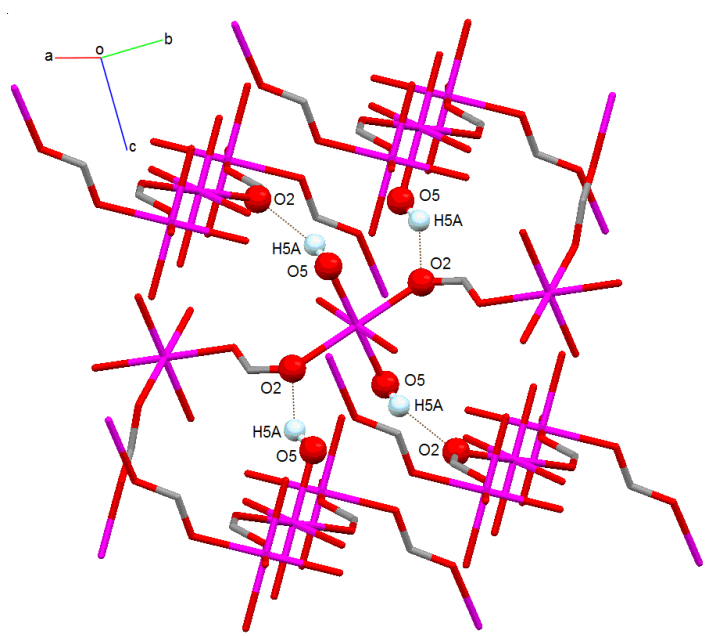

Fig. 3. View of an infinite 2D-layer supramolecular structure of the title complex on the ab crystallographic plane

\begin{tabular}{|c|c|c|c|c|}
\hline \multicolumn{5}{|c|}{$\begin{array}{c}\text { TABLE-3 } \\
\text { HYDROGEN-BONDING DATA }\left[\AA,{ }^{\circ}\right]\end{array}$} \\
\hline D-H $\cdots A$ & $d(D-H)$ & $\mathrm{d}(\mathrm{H} \cdots \mathrm{A})$ & $\mathrm{d}(\mathrm{D} \cdots \mathrm{A})$ & $\angle \mathrm{D}-\mathrm{H} \cdots \mathrm{A}$ \\
\hline O5-H5A ‥ 2 & 0.85 & 1.98 & $2.725(5)$ & 145 \\
\hline $\mathrm{O} 5-\mathrm{H} 5 \mathrm{~B} \cdots \mathrm{O} 4$ & 0.85 & 2.00 & $2.773(5)$ & 150 \\
\hline O6-H6A ‥O1 & 0.85 & 1.95 & $2.739(5)$ & 155 \\
\hline O6-H6B $\cdots \mathrm{O} 3$ & 0.85 & 1.94 & $2.774(5)$ & 168 \\
\hline
\end{tabular}

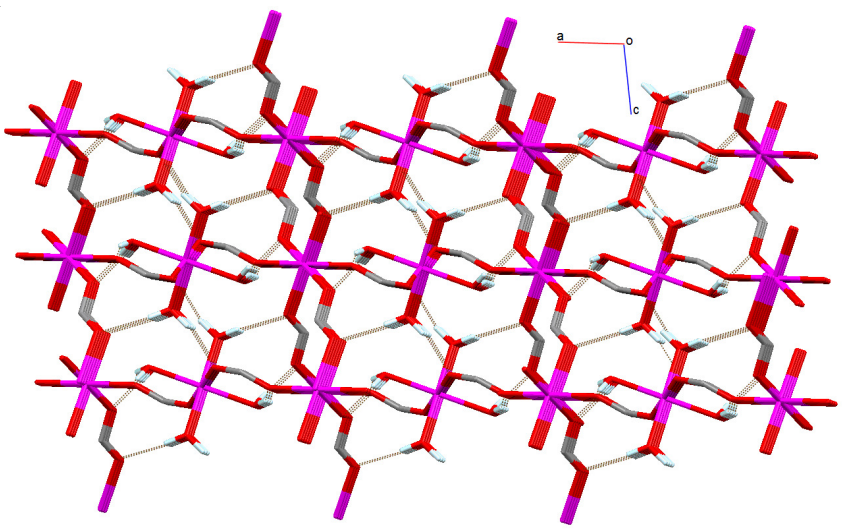

Fig. 4. View of an infinite 3D supramolecular network of the title complex

\section{ACKNOWLEDGEMENTS}

This work was supported by the Foundation of Preparative Research of Jin-Chuan Corporation (grant No. 420032) is gratefully acknowledged.

\section{REFERENCES}

1. D.M. Boghaei, A. Bezaatpour and M. Behzad, J. Mol. Catal. A, 245, 12 (2006).

2. W.K. Dong, Y.X. Sun, Y.P. Zhang, L. Li, X.N. He and X.L. Tang, Inorg. Chim. Acta, 362, 117 (2009).

3. W.K. Dong, G. Wang, S.S. Gong, J.F. Tong, Y.X. Sun and X.H. Gao, Transition Met. Chem., 37, 271 (2012).

4. W.K. Dong, J.G. Duan, Y.H. Guan, J.Y. Shi and C.Y. Zhao, Inorg. Chim. Acta, 362, 1129 (2009).

5. W.K. Dong, X.N. He, H.B. Yan, Z.W. Lv, X. Chen, C.Y. Zhao and X.L. Tang, Polyhedron, 28, 1419 (2009).

6. S. Akine, T. Taniguchi and T. Nabeshima, Angew. Chem. Int. Ed., 41, 4670 (2002).

7. S. Akine, W.K. Dong and T. Nabeshima, Inorg. Chem., 45, 4677 (2005).

8. W.K. Dong and Y.J. Ding, Cryst. Res. Technol., 43, 321 (2007).

9. W.K. Dong, J.Y. Shi, J.K. Zhong, Y.X. Sun and J.G. Duan, Struct. Chem., 19, 95 (2008).

10. W.K. Dong, J.Y. Shi, J.K. Zhong, Y.Q. Tian and J.G. Duan, Chin. J. Inorg. Chem., 24, 10 (2008).

11. S. Akine, T. Taniguchi and T. Nabeshima, Chem. Lett., 30, 682 (2001).

12. G.M. Sheldrick, SHELXS97, Program for Crystal Structure Determination, University of Göttingen, Germany (1996).

13. G.M. Sheldrick, Acta Cryst., A64, 112 (2008). 